\title{
鼠 \\ KONTRIBUSI FILSAFAT PERENIAL DALAM MEMINIMALISIR GERAKAN RADIKAL
}

\author{
Muhammad Nur \\ IAIN Raden Intan Lampung \\ m.nur@iainradenintan.ac.id
}

\begin{abstract}
Abstrak
Artikel ini menawarkan suatu solusi strategis yang dapat diterapkan dalam rangka mengcounter dan mencegah berkembangnya ideologi radikal melalui pendekatan filsafat perennial. Agama, pada satu sisi, bisa menjadi sumber perdamaian. Namun, pada sisi yang lain, agama juga bisa dijadikan stimulan untuk menciptakan konflik. Titik lemah inilah yang dimanfaatkan oleh kelompok radikal-fundamentalis untuk menjadikan agama sebagai alat jastifikasi bagi aksi dan propaganda mereka. Dengan menggunakan pendekatan filsafat perennial, propaganda ekslusifisme yang dikembangkan oleh kelompok radikal dapat dilawan. Lebih jauh lagi, Melalui cara ini pula, upaya memperkuat konsep Bhinneka tunggal Ika dalam rangka membangun masyarakat Indonesia yang sadar pluralitas dapat lebih mudah dilaksanakan.
\end{abstract}

abstract

This article offers a strategic solution that can be applied to counter and minimize the development of radical ideology through the use of perennial philosophical approach. Religion, on the one hand, could be a source of peace. On the other hand, however, religion can also be used as a stimulant to create conflict. This weak point of religion is utilized by radical groups to justify their action and propaganda. By utilizing perennial philosophy, the ecxclusivism propaganda developed by radical groups can be countered. Similarly, efforts to strengthen the concept of Unity in Diversity to build plurality awareness among the Indonesian society can be more easily implemented.

Kata kunci: Filsafat Perennial, Agama, Radikal, fundamental 


\section{A. Pendahuluan}

Secara umum, agama adalah panduan dan juga jalan bagi manusia guna memperoleh kebahagiaan hidup di dunia dan akhirat. Sebagai sesuatu yang diyakini berasal dari Tuhan Sang Maha Pencipta, maka panduan tersebut diturunkan dalam bentuk wahyu yang disampaikan melalui para Nabi-Nya. Melalui wahyu tersebut, agama kemudian memberikan pemahaman kepada manusia bagaimana caranya untuk hidup selaras, tidak hanya dengan lingkungan yaitu alam dan manusia bahkan juga dengan Tuhan itu sendiri.

Dalam perspektif yang lebih luas, agama bukan hanya kumpulan ajaran moral, namun lebih dari itu adalah perjumpaan dengan Yang Ilahi. Dengan demikian, hakikat agama yang adalah keyakinan akan adanya kekuatan gaib yang maha tinggi dan tidak bisa dipisahkan dari kehidupan menjadi sangat perlu dipahami secara seksama oleh setiap manusia. Dalam memahami agama, manusia harus lebih terbuka, maksudnya selain melihat perbedaan bentuk, manusia juga harus melihat substansinya. Hal tersebut agar manusia tidak terjebak pada pemahaman yang dangkal tentang agama, sehingga menyebabkan timbulnya truth claim yang berlebihan.

Hakikat agama yang demikian, pada penganutnya diyakini dapat mendatangkan rasa aman dan damai dalam kehidupan, karena agama berisi petunjuk kehidupan dalam semua aspeknya, yang dalam hal ini termasuk kehidupan sosial, yakni lingkungan manusia berinteraksi. Setiap individu dengan berbagai karakter, kepentingan, dan keyakinan harus dapat menyesuaikan diri dan saling menghormati. Ketidakmampuan manusia beradaptasi dalam kehidupan sosial akan menyebabkan munculnya konflik. Keberagaman masyarakat adalah modal bagi kehidupan sosial yang damai. Agama menjadi salah satu bagian dari keberagaman masyarakat. Setiap agama memiliki satu bentuk dan juga satu substansi. Dalam perspektiffilsafat perennial, substansi mempunyai hak-hak yang tidak terbatas, sebab ia lahir dari yang mutlak sedangkan bentuknya relatif, dan karena itu hak-haknya terbatas. Menurut kelompok perenialis, kebenaran Mutlak hanyalah satu dan tidak terbagi, tetapi dari yang satu memancarkan beragam 
kebenaran. Metafisika diasumsikan sebagai sumber kebenaran yang mutlak. Sementara itu, pembahasan tentang agama itu sendiri bersifat perenial karena abadi, yang artinya selalu diperbincangkan kapan saja.

Pada masa postmodern ini manusia semakin dihadapkan dengan kenyataan multikulturalitas dan pluralitas yang tidak dapat dihindari keberadaannya. Setiap agama akan berjumpa dengan agama-agama lain, sehingga mau tidak mau ia harus mendefenisikan secara teologis dan metafisik tentang bagaimana hubungannya dengan agama lain. Filsafat perenial dianggap bisa menjelaskan kejadian yang bersifat hakiki, menyangkut kearifan yang diperlukan dalam menjalankan hidup yang benar yang rupanya menjadi hakikat dari seluruh agama-agama dan tradisitradisi besar spiritualitas manusia. ${ }^{1}$

Indonesia merupakan negara yang majemuk, yang dalam hal ini secara faktual bisa dilihat dari keanekaragaman yang ada di dalamnya, antara lain agama, budaya, suku, dan bahasa. Di sisi lain, keanekaragaman antara satu dengan yang lain jika tidak berjalan selaras dengan konsep dasar kebhinekaan, akan menyebabkan lahirnya klaim kebenaran yang eksklusif yaitu tertutup bagi kebenaran lain. Hal tersebut akan mengakibatkan disharmonisasi manusia yang berdampak negatif pada berjalannya pembangunan di sebuah negara. Dalam wilayah agama, klaim kebenaran yang radikal ini memunculkan sikap bahwa ajaran agama yang diyakininya adalah satu-satunya kebenaran mutlak dengan diikuti pandangan bahwa keyakinan orang lain pasti salah dan harus dimusnakan. Sejalan dengan itu, menurut Komarudin Hidayat, agama selalu tampil dalam dua wajah, yaitu sebagai kekuatan konstruktifdan sekaligus destruktif. Sisi destruktif agama seringkali dipicu oleh adanya sikap radikal dari penganut agama. Pada masa orde baru, sikap-sikap fundamentalis dan radikal penganut agama cenderung tidak terlihat secara nyata, hal ini disebabkan sikap represif pemerintah yang tidak mentolerir hal-hal yang mengancam stabilitas politik dan keamanan Negara. Meskipun pada saat yang sama sikap ini justru memperkuat semangat ekstrimisme agama

${ }^{1}$ Komaruddin Hidayat, Muhammad Wahyuni Nafis, Agama Masa Depan Perspektif Filsafat Perenial (Jakarta: Paramadina,1995), h.xx. 
kelompok radikal tersebut. Sementara itu pasca reformasi, seiring dengan terbuka lebarnya kran kebebasan dalam segala hal sebagai bagian dari euforia demokrasi, maka bibit-bibit radikalisme yang telah lama tersemai pun menemukan titik tolaknya. Bahkan Hizbut Tahrir Indonesia yang meskipun sering mengklaim diri sebagai kelompok Islam moderat, namun pada kenyataannya memperjuangkan tegaknya Khilafah Islamiyah, suatu hal yang jelasjelas bertentangan dengan konstitusi di Indonesia pun bisa berdiri dan menyebarkan ideologinya secara leluasa. Suatu fenomena yang tidak pernah terbayangkan bisa terjadi pada masa orde baru.

Di samping itu, konflik-konflik keagamaan yang terjadi di sebagian wilayah Indonesia yang terjadi menahun seperti di Ambon dan Poso, lalu pembakaran masjid di Papua pada saat Idul Fitri beberapa waktu, belum lagi penanganan kasus terorisme yang cenderung tendensius dan tidak adil dengan menempatkan umat Islam sebagai target operasi kiranya semakin mempertebal paham radikalisme di Indonesia. Gerakan radikal dan fundamental dalam bidang agama yang dipicu oleh klaim kebenaran atau klaim keselamatan eksklusif bagi penganutnya mau tidak mau akan ikut menyumbangkan kwantitas maupun kwalitas konflik di Indonesia. Konflik tersebut selain akan berujung pada kerusakan properti bahkan juga pada hilangnya nyawa. Dengan demikian, bisa disimpulkan bahwa gerakan-gerakan radikalisme dan fundamentalisme di Indonesia ikut menyumbangkan problemproblem serius dalam jalannya pembangunan dan kehidupan berbangsa dan bernegara. Pembangunan yang telah dilakukan, sedang berjalan, dan akan direncakan pada akhirnya menjadi terganggu. Dalam konteks inilah tulisan ini dibuat. Tulisan ini akan menjawab persoalan-persoalan yang dapat muncul dari gerakan radikal dan fundamental dalam hubungannya dengan kehidupan bernegara. Selanjutnya juga akan dijelaskan juga bagaimana peran filsafat perennial dalam menjawab persoalan tersebut sebagai tawaran solusi. Tujuan utama tulisan ini adalah pada bagaimana tereliminasinya gerakan fundamentalis dan radikal dalam bidang keagamaan melalui telaah filsafat perennial agar terciptanya kehidupan berbangsa dan bernegara yang aman dan damai. 


\section{B. Radikalisme dan Fundamentalisme Agama sebagai Penghambat Pembangunan Bangsa}

Secara umum istilah radikalisme sering kali didasarkan dari kata radikal yang artinya adalah ekstrim, menyeluruh, fanatik, revolusioner, ultra dan fundamental. Radikalisme bisa juga diartikan dengan doktrin atau praktik penganut paham radikal atau ekstrim. ${ }^{2}$ Dalam wacana kontemporer atau populer, radikalisme keagamaan sering juga disebut dengan fundamentalisme agama yaitu paham yang pada awalnya dinisbahkan pada sebuah gerakan teologi agama Kristen di Barat. Seperti yang dikemukakan oleh Karen Armstrong bahwa orang Protestan Amerika lah yang pertama kali menggunakan istilah tersebut. ${ }^{3}$ Dengan ini kaum fundamentalis ingin kembali ke dasar-dasar dan menekankan kembali "fondasifondasi" tradisi Kristen. Karen Armstrong juga menambahkan bahwa sejak saat itu istilah fundamentalisme kemudian digunakan pada gerakan-gerakan pembaharuan di dalam agama-agama di dunia lain dengan cara yang jauh dari memuaskan. ${ }^{4}$ Pada kenyataannya fundamentalisme tidak lah monopoli agama besar saja. Ternyata ada pula fundamentalisme pada agama Buddha, Hindu, dan bahkan Konghucu. Para fundamentalis sering kali berperang, membunuh, juga meneror atas nama agama dan berusaha membawa "yang kudus" ke dalam wilayah politik dan pergulatan nasional. ${ }^{5} \mathrm{Hal}$ ini lah yang coba dicermati oleh Karen Armstrong dalam melihat konflik ArabIsrael. Armstrong mengkritik fundamentalis Muslim dan Yahudi yang menafsirkan konflik Arab-Israel sebagai konflik keagamaan, padahal menurutnya konflik tersebut jelas-jelas bermula sebagai konflik sekuler. ${ }^{6}$

Dalam konteks keindonesiaan hal tersebut ternyata juga berlaku. Seperti yang diuraikan di atas, gerakan radikalisme di berbagai negara, termasuk Indonesia, menginformasikan bahwa

${ }^{2}$ Imam Tolkhah, Paham dan Pemikiran Islam Radikal Pasca Orde Baru, dalam "Direktori Kasus-Kasus Aliran, Pemikiran, Paham, dan Gerakan Keagamaan di Indonesia (Jakarta: BALITBANG KEMENAG RI, 2010), h. 5

3 Karen Armstrong, Berperang demi Tuhan; Fundamentalisme dalam Islam, Kristen, dan Yahudi (Bandung: Mizan, 2013) h. 16.

${ }^{4}$ Ibid. h. 17

${ }^{5}$ Ibid. h. 16

${ }^{6}$ Ibid 
munculnya gerakan radikal bukan monopoli agama atau suku tertentu (ethnoreligious), namun lahir kapan saja dari semua kelompok sosial dan politik. Gerakan yang bersifat radikal telah menjadi salah satu instrumen untuk mencapai tujuan atau kepentingan tertentu. Dalam penelitiannya, Imam Tolkhah menulis bahwa radikalisme lahir karena kesadaran bahwa kelangsungan hidup kelompok itu tertindas, terpinggirkan, dan terancam oleh kelompok yang lebih mapan.

Di Indonesia, radikalisme sendiri ternyata tidak melulu berhubungan dengan agama. Sehingga Imam Tolkhah membagi gerakan radikal pada dua kelompok, yaitu "radikal permanen" dan "radikal sementara". ${ }^{\circ}$ Secara umum gerakan radikal permanen adalah kelompok yang sepanjang sejarah memiliki karakter radikal. Biasanya kelompok ini disebut kelompok ekstrim kiri atau ekstrim kanan. Kelompok ekstrim kiri sering diasosiasikan dengan gerakan kelompok berpaham sosialisme dan marxisme yang dalam pergerakannya cenderung revolusiner. Tema yang sering dijadikan jargon gerakan adalah pembelaan terhadap kaum miskin dan tertindas (proletar, buruh). Sementara itu kelompok ekstrim kanan diidentikkan dengan kelompok fundamentalis, yakni kelompok yang mengikuti paham dan ideologi agama dan moral yang kuat. Tema utama perjuangannya adalah menegakkan hukum agama sebagai hokum publik demi keluhuran budi, moral dan sirnanya kemaksiatan. ${ }^{9}$

Melihat pada kenyataan sejarah, dua kelompok gerakan radikal permanen di atas telah beberapa kali mengganggu stabilitas politik bangsa Indonesia bahkan sejak awal kemerdekaan. Kelompok ekstrim kiri melalui PKI-nya telah beberapa kali melakukan pemberontakan demi mewujudkan negara komunis-sosialis. Begitu juga dengan kelompok ekstrim kanan yang pernah mencoba mendirikan negara berasaskan agama. Melalui anggota Masyumi yang menjadi wakil dalam Badan Penyelidik Usaha Persiapan Kemerdekaan Indonesia (BPUPKI) mereka mengusulkan Indonesia menjadi Negara Islam. Meskipun pada akhirnya tidak terwujud,

\footnotetext{
${ }^{7}$ Imam Tolkhah, Paham dan.... h. 6

${ }^{8}$ Ibid. h. 7

${ }^{9}$ Ibid
} 
namun hingga sekarang, masih banyak kelompok dengan ideologi sejenis yang mencoba untuk menjadikan Indonesia sebagai negara Islam atau minimal berasaskan Islam.

Selain memperjuangkan lahirnya negara Islam dengan jalur politik yang akomodatif, namun pada kenyataannya gerakan radikal permanen tidak sedikit yang mencoba memperjuangkan lahirnya negara Islam dengan cara-cara kekerasan dan ekstrim. Hal ini bisa dilihat pada kelompok Darul Islam/Tentara Islam Indonesia yang dipelopori dan dipimpin oleh Selo Mardjan Karto Suwiryo. Meski kemudian gerakan tersebut dapat ditumpas oleh pemerintah, namun gerakan "turunannya" masih terus tumbuh melanjutkan ideologi Negara Islam Indonesia. Hal ini bisa dilihat pada kelompok Komando Jihad, peristiwa Teror Warman, Kasus pembajakan pesawat Woyla di Bangkok, Peristiwa Tanjung Priok, Talangsari Lampung dan akhirnya muncul dalam organisasi teroris seperti al-Jamaah al-Islamiyah.

Apayang diuraikandalamsubbabiniadalah barumerupakan fenomena konflik fundamentalisme dan radikalisme dalam wilayah agama Islam saja. Belum lagi jika dihubungkan dengan konflik horizontal antar agama . Sampai di sini bisa disimpulkan bahwa konflik-konflik yang timbul tersebut mengakibatkan terganggunya stabilitas politik, ekonomi, keamanan, yang bermuara pada terhambatnya pembangunan nasional. Kemudian jika dianalisa lebih lanjut, setiap gerakan radikal dan fundamental yang muncul tersebut selalu bertitik tolak pada klaim kebenaran yang dimiliki. Fundamentalis agama selalu merasa bahwa merekalah yang merupakan kelompok yang paling sah mewakili ajaran-ajaran Tuhan di muka bumi. Sehingga muncullah logika dikotomik; jika bukan pasukan Tuhan, maka artinya adalah sebaliknya yaitu musuhNya. Hal ini lah yang kemudian mendorong terjadinya serangan 11 September 2001 yang diduga dilakukan oleh kelompok al-Qaeda sehingga meluluh lantakkan Gedung World Trade Centre dan Sayap Pentagon. Selanjutnya tak kalah mengejutkannya, di Indonesia juga terjadi peristiwa Bom Bali yang dilakukan oleh Amrozi Cs yang kemudian disusul oleh Bom di Hotel Marriot dan lain-lain. Hal ini semakin mempertegas dan mengafirmasi bahwa ekses-ekses 
dari gerakan fundamentalis radikal tersebut sangat mengganggu terselenggaranya kehidupan berbangsa dan bernegara.

\section{Urgensi Filsafat Perenial dalam Kehidupan Berbangsa dan Bernegara}

Filsafat perenial atau perenialisme sebenarnya adalah sebuah wacana filsafat yang tua, yang ada pada masa pramodern, namun diklaim sebagai yang tetap aktual sepanjang masa. Persoalan yang dibahas dalam filsafat perenial antara lain tentang Tuhan dan eksistensinya sebagai realitas absolut yang kekal, kemudian tentang pluralitas agama yang meupakan kenyataan yang tidak bisa dihindari dalam kehidupan, selanjutnya tentang simbolsimbol yang menjadi identitas keagamaan.

Sejak dulu, perjumpaan antara pemeluk berbagai agama telah terjadi. Dari perjumpaan itu telah dihasilkan banyak kerja sama, namun tak sedikit pula yang mengakibatkan perselisihan, bahkan peperangan. Dari sudut keyakinan, perselisihan antar pemeluk agama biasanya terjadi akibat klaim eksklusif atas wahyu keselamatan yang dimiliki. Pada awalnya, klaim eksklusif merupakan penegasan akan identitas khas suatu kelompok agama yang berbeda dengan agama kelompok lain. Tetapi dalam perkembangan selanjutnya, suatu kelompok agama berusaha menunjukkan, bahkan memaksakan, klaim keselamatan eksklusif tersebut pada orang lain yang sebenarnya juga telah memiliki suatu klaim keselamatan eksklusif. Pertentangan klaim eksklusif inilah yang merupakan salah satu sebab, di samping sebab-sebab yang lain, timbulnya peperangan antaragama. ${ }^{10}$

Pada negara-negara yang sedang berkembang seperti Indonesia, perubahan-perubahan masyarakat terdiri dari dua macam, yang pertama adalah perubahan sosial yang disebabkan oleh usaha pembangunan negara. Yang kedua adalah proses perubahan sosial jangka panjang yang berjalan hampir-hampir otonom (pemerintahan sendiri), seperti yang diakibatkan oleh bertambahnya penduduk, berkembangnya teknologi dan sains, pengaruh komunikasi dengan dunia luar dan lain sebagainya.

${ }^{10}$ Ali Noer Zaman, Agama Untuk Manusia (Yogyakarta: Pustaka Pelajar, 2000), h. vi. 
Berbicara mengenai pembangunan, erat hubungannya dengan manusia. Hal ini disebabkan manusia adalah subjek sekaligus objek dalam pembangunan. Bagaimana suatu bangsa dapat memiliki kualitas yang baik jika manusianya tidak memiliki kualitas yang baik pula dalam memainkan peran sebagai agen pembangun. Lebih disadari bahwa usaha untuk menentukan tujuantujuan pembangunan suatu bangsa tidak bisa dilepaskan dari ruang lingkup moral yang merupakan titik awal tempat berpijak. Sehingga untuk mewujudkan pembangunan yang berhasil maka yang pertama disentuh adalah pembangunan manusia seutuhnya.

Pembangunan merupakan sebuah usaha yang dilakukan secara sadar dan terencana untuk mewujudkan perubahan yang diinginkan. Dalam pembangunan manusia terdapat dua bentuk yang menyertainya, yaitu pembangunan manusia secara fisik dan non fisik. Pembangunan fisik berbentuk infrastruktur sedangkan pembangunan non fisik berbentuk pembinaan. Baik itu pembangunan fisik maupun non fisik keduanya penting dan saling mempengaruhi, namun dalam hal ini akan ditujukan pada pembangunan non fisik berupa pembangunan mental spiritual manusia yang dapat diartikan sebagai pembangunan pada budi pekerti, pendidikan, keagamaan, termasuk moral, kebudayaan dan kesenian. Dalam pembangunan fisik juga di barengi dengan pembangunan moral agar infrastruktur yang di bangun tepat sasaran dan mencapi tujuan yang dinginkan.

Dalam melaksanakan usaha pembangunan mental spiritual manusia tentu terdapat peran serta agama di dalamnya. Agama merupakan petunjuk sekaligus jalan yang ditempuh seseorang untuk mendekatkan diri kepada Yang Maha Kuasa. Para ahli melihat paling tidak terdapat tiga sikap orang dalam beragama. Pertama, sikap ekslusif yaitu sikap yang menganggap bahwa agama-agama lain adalah jalan yang salah, yang menyesatkan bagi pengikutnya. Kedua, inklusif yaitu sikap yang menganggap bahwa agama-agama lain adalah bentuk implisit (tersirat) suatu agama tertentu. Ketiga, pluralis yaitu sikap yang ditunjukkan oleh para kaum perenialis, yang terekspresikan dalam macam-macam rumusan. Misalnya agama-agama lain adalah jalan yang sama-sama sah untuk mencapai kebenaran yang sama. 
Agama-agama lain berbicara secara berbeda, tetapi merupakan kebenaran yang sama-sama sah. Atau setiap agama mengekspresikan bagian penting sebuah kebenaran. Kemajemukan dan pluralitas apabila tidak diimbangi dengan toleransi yang dibangun dengan pemahaman esoterik tentang Tuhan yang benar, dapat menimbulkan truth claim radically dan intoleransi yang sangat membahayakan integritas bangsa. ${ }^{11}$

Adanya klaim kebenaran pada dataran eksoterisme selama bersifat internal adalah benar dan justru sangat diperlukan, karena bagaimana mungkin melaksanakan ajaran agama tanpa ada keyakinan bahwa ajaran itu benar. Hanya yang menjadi persoalan adalah ketika klaim itu bersifat eksternal sehingga menempatkan agama lain pada posisi lawan. Hal tersebut dapat menghambat pembangunan nasional suatu bangsa. Manusia yang seharusnya sebagai agen perubahan dan pembangun, karena memiliki klaim yang eksklusif tidak dapat melakukan sebuah kerjasama untuk mencapai tujuan pembangunan yang diinginkan.

Dari pandangan sekilas mengenai isi, pelaksanaan dan penampilannya, agama nampak berbeda, bahkan berlawanan satu sama lain. Namun bila dilihat intinya, semua agama pada dasarnya mempercayai, meyakini dan berpegang pada hal yang sama, yaitu Realita, Dzat, atau Sesuatu yang Maha Tinggi yang disebut sebagai Tuhan, Allah, Yahweh, God. Tuhan tak terbatas kesempurnaan-Nya, bersifat transenden (teramat jauh bahkan tidak terjangkau) tetapi sekaligus imanen (berada bersama, bahkan di dalam diri kita).

Setiap agama tentu mengakui bahwa agama dan Kitab Sucinya itu bersifat konsisten, dan penuh dengan kebenaran tanpa kesalahan sama sekali, bersifat lengkap dan final sehingga tidak diperlukan kebenaran lain, apalagi kebenaran dari agama baru. Juga agama mana yang tidak mengakui bahwa agamanya lah yang merupakan satu-satunya jalan keselamatan, jalan pencerahan atau jalan pembebasan. Apalagi Kitab Suci yang menjadi rujukan memang betul-betul berasal dari Tuhan. Jika diekstrimkan hal tersebut akan menyumbangkan masalah besar. Khususnya jika suatu agama berhadapan dengan agama lain. Masalah yang muncul

${ }_{11}$ Arqom Kuswanjono, Ketuhanan dalam Telaah Filsafat Perenial Refleksi Pluralisme Agama di Indonesia, (Yogyakarta: CV Arindo Nusa Media, 2006), h. 5. 
adalah perang klaim kebenaran (truth claim), dan selanjutnya perang kalim penyelamatan (salvation claim).

Satu fenomena menarik terkait dengan eksistensi agama di tengah kehidupan sosial adalah munculnya konflik sosial yang berlatar belakang keanekaragaman agama seperti yang dipaparkan di atas. Loyalitas total seorang penganut agama terhadap agamanya seringkali menyebabkan konflik dengan penganut agama yang berbeda. Persoalannya, apakah kehidupan bersama yang damai yang di ajarkan oleh setiap agama harus dikorbankan atas nama agama, bagaimana bentuk dan dimanakah batas loyalitas terhadap agama dalam konteks heterogenitas masyarakat? Karena itu, kehidupan manusia yang kian destruktif dan artifisial (dangkal) tersebut tidak mungkin terselamatkan, kecuali manusia melakukan revolusi berpikir.

Filsafat perenial merupakan cabang dari filsafat yang mengatakan kebenaran Mutlak hanyalah satu tidak terbagi, tetapi dari yang satu memancarkan berbagai kebenaran. Sehingga dalam memahami suatu hal filsafat perenial tidak hanya berangkat dari aspek bentuk, tetapi juga substansinya. Begitu pula dalam memahami agama, filsafat perenial membahas secara lebih universal melalui berbagai macam pendekatan. Lalu bagaimana urgensi filsafat perenial bagi pembangunan manusia? Karena manusia merupakan subjek dan objek dalam mewujudkan pembangunan bangsa, maka untuk membangun bangsa pada hakikatnya adalah membangun manusia seutuhnya yaitu dengan cara membangun mental spiritualnya terlebih dahulu.

Dalam kehidupan kemanusian yang kian mengglobal, kita tidak bisa lagi hidup dengan visi-visi ekslusif (tertutup). Manusia harus belajar hidup dan bertingkah laku yang lebih sensitif satu sama lain dan menganggap, misalnya orang-orang yang keberadaannya lebih jauh adalah sama pentingnya. Seluruh tradisi besar keagamaan sama-sama mengakui sangat pentingnya kedermawanan dan kebajikan satu sama lain. Menemukan bahwa agama masing-masing individu memiliki kesamaan dengan agamaagama lain merupakan pengalaman yang menguatkan. Jadi, tanpa meninggalkan tradisi, manusia dapat belajar dari yang lain-lain 
tentang kehidupan manusia dan peradaban yang lebih baik dan lebih mencerahkan.

Dalam bukunya Islam Inklusif, Alwi Shihab dengan mengutip Muhammad Abduh berpendapat bahwa syarat pertama beriman kepada Allah tidak harus dibatasi dengan keimanan menurut cara Islam. Selanjutnya Rasyid Ridha murid Abduh ikut memperkuat pendapat gurunya. Ia mengakui bahwa keimanan sejati kepada Allah dapat juga di temukan di luar Islam yang di bawa Nabi Muhammad saw. Mungkin yang ia maksud adalah orang-orang yang terdahulu yang beriman kepada Allah sebelum di utusnya Nabi Muhammad saw. Al-Thabathabai lain pula penafsifannya. Baginya, Allah tidak memandang pada agama tertentu, tapi yang penting adalah substansi dan esensi yang terkandung dalam agama itu. ${ }^{12}$

Agama merupakan petunjuk bagi umat manusia untuk menyebarkan perdamaian dan memberikan solusi terhadap persoalan kehidupan. Akan tetapi mengapa ketika agama dilibatkan justru persoalan menjadi semakin meruncing, bahkan mereka (para penganut agama) rela saling membunuh atas nama agama yang diyakininya. Kondisi demikian tidak menutup kemungkinan akan memunculkan sikap tidak percaya terhadap fungsi/ manfaat agama dalam rangka mengatasi persoalan-persoalan kehidupan, yang oleh Komarudin Hidayat dikatakan sebagai kegagalan peran sosial agama.

Ketika agama dalam dataran eksoterik menganggap sebagai satu-satunya yang paling benar dan dengan serta merta menyalahkan agama lain, maka agama akan kehilangan esensi sebagai pengendali kekacauan dan justru malah menjadi pemicu perpecahan.Anggapan Marxyang mengatakan bahwa agama sebagai suatu candu yang memabukkan dan melenakan itu masih tidak begitu membahayakan, akan tetapi justru yang membahayakan adalah ketika seseorang menggunakan legitimasi agama untuk menghina orang lain, menganiaya orang lain, membunuh orang lain/ berperang demi memperjuangkan kebenaran agama yang diyakini. Suatu sikap yang ambivalen dalam beragama, yaitu disatu

${ }^{12}$ Alwi Shihab, Islam Inklusif Menuju Sikap Terbuka Dalam Beragama (Bandung: Mizan, 1997), h. 80. 
sisi agama mengajarkan perdamaian dan kasih sayang, disisi lain agama justru dianggap sumber perpecahan dan kerusuhan.

Melihat permasalahan yang begitu mencolok dan berbeda dalam memahami hakikat agama, sangat berpengaruh pula pada pembangunan mental spiritual manusia yang akhirnya akan berdampak pada pembangunan nasional karena manusia merupakan subjek dan objek yang akan melakukan pembangunan. Maka dari itu kesalahpahaman ini tidak dapat dibiarkan begitu saja. Filsafat perenial dapat menjadi alternatif yang memberikan kontribusi dalam hal pembangunan mental spiritual manusia, mengembalikan pemahamannya pada agama yang hanif, agama yang damai, agama yang terbuka terhadap kebenaran lain. Filsafat perenial melakukan pembangunan mental spiritual manusia dengan menggunakan pendekatan fenomenologi dan studi agama dalam dataran normatifitas dan historisitas.

Fenomenologi adalah sebuah studi pendekatan dengan cara melihat berbagai macam gejala dari bidang yang sama antara berbagai macam agama, misalnya cara penerimaan penganut, dalam ritus dan kultus, sehingga diperoleh hakikat yang sama dari gejala yang berbeda. Dengan demikian ketika seseorang dihadapkan dalam kenyataan faktual yang menampilkan berbagai keanekaragaman khususnya dalam bentuk agama, dan dapat memiliki wawasan yang lebih terbuka sehingga terhindar dari sifat diversitas yaitu kondisi kemajemukan yang satu dengan yang lain tidak ada saling hubungan dan tidak pula saling menyapa, sehingga hal tersebut dapat menyebabkan disintegrasi.

Pendekatan fenomenologi bukan saja mengetahui apakah itu, tetapi juga mengetahui bagaimana hal itu terjadi. Sehingga tidak mengajukan suatu sistem pemikiran yang eksklusif. Sejarah agama pertama-tama berurusan dengan agama dalam lingkupnya masing-masing, perkembangannya dan hubungannya dengan nilai-nilai budaya lain yang termasuk dalam lingkup yang sama. Fenomenologi agama tidak bermaksud memperbandingkan agamaagama sebagai satuan-satuan besar, melainkan menarik fakta dan fenomena yang sama, yang dijumpai dalam agama-agama yang berlainan, mengumpulkan dan mempelajarinya perkelompok. Tujuannnya adalah memperoleh suatu pandangan yang lebih 
dalam dan seksama. Dalam fenomenologi, kita mempertimbangkan fenomena agama bukan hanya dalam konteks historis mereka, melainkan juga dalam hubungan struktural mereka. Jadi, perlu dibedakan antara sejarah Agama dan sejarah dari agama tertentu. ${ }^{13}$

Pendekatan fenomenologi tidak hanya menghasilkan suatu penelitian mengenai fenomena yang dipelajari, namun memberikan arti yang lebih dalam dari suatu fenomena religius. Fenomenologi agama adalah ilmu empiris yang menggabungkan ilmu-ilmu lain seperti psikologi, sosiologi, dan antropologi, sehingga fenomenologi agama lebih dekat dengan filsafat agama, karena mempelajari fenomena religius dalam aspeknya yang khas dari kereligiusan. ${ }^{14}$

Selanjutnya pendekatan yang dilakukan filsafat perenial untuk membangun manusia dalam hal mental spiritualnya adalah dengan memberikan pemahaman bahwa keanegaraman bentukbentuk yang ditampilkan agama ini hendaknya dilihat dalam dua aspek, yaitu aspek normatif dan historis. Secara normatif, seseorang akan cenderung mengabsolutkan teks yang sudah tertulis tanpa berusaha memahami terlebih dahulu apa sesungguhnya yang melatarbelakangi berbagai teks keagamaan yang ada. Sedangkan secara historis, ingin menggarisbawahi pentingnya telaah yang mendalam tentang "asbabunuzul" baik yang bersifat kultural, psikologis, maupun sosiologis.

Hubungan antara keduanya tidak harus mengambil posisi yang berhadap-hadapan dan bersifat dikotomis. Hubungan antara keduanya ibarat sebuah koin dengan dua permukaan. Hubungan antara kedua permukaan koin tidak dapat dipisahkan, tetapi secara tegas dan jelas dapat dibedakan. Keduanya teranyam, terjalin dan terajut sedemikian rupa sehingga keduanya menyatu dalam kesatuan yang utuh dan kokoh. Makna terdalam dan moralitas keagamaan tetap ada, tetap dikedepankan dan digarisbawahi dalam memahami lika-liku fenomena keberagamaan manusia, tetapi begitu makna dan moralitas keberagamaan tadi memasuki wilayah historisitas kehidupan sehari-hari manusia, maka ia secara

${ }^{13}$ Mariasusai Dhavamony, Fenomenologi Agama (Yogyakarta: Kanisius, 1995), h. 26 .

${ }^{14}$ Ibid, h. 4. 
otomatis tidak bisa terhindar dari belenggu dan jebakan ruang dan waktu. ${ }^{15}$

Dengan memahami agama menggunakan pendekatan yang ditawarkan oleh filsafat perenial yaitu pendekatan fenomenologi dan pendekatan normatif-historis, maka seseorang akan memiliki sikap yang lebih terbuka dalam melihat keberagaman yang ada di sekitarnya. Sehingga tujuan pembangunan untuk mewujudkan hidup yang lebih baik dapat terlaksana dengan jalan kerjasama. Manusia yang memiliki mental spiritual yang baik dan sebagai subjek pembangunan dapat melaksanakan tugasnya tanpa mempermasalahkan perbedaan bentuk yang muncul dalam agama, karena sebenarnya perbedaan-perbedaan tersebut terjadi karena faktor historisitas dan kebudayaan masyarakat yang berbeda-beda. Selanjutnya filsafat perenial mengarahkan pada pemahaman tentang kesatuan transenden dalam agama yaitu dalam dataran esoterik.

Dengan menggunakan basis pemahaman filsafat perennial, maka semboyan Bhinneka Tunggal Ika yang merupakan pedoman dasar bangsa Indonesia dalam melihat perbedaan akan menemukan titik perannya. Seperti halnya filsafat perennial yang meyakini bahwa hakikat kenyataan pada dasarnya berasal dari yang Tunggal, maka Bhinneka Tunggal Ika juga memandang bahwa betapapun banyaknya perbedaan suku, agama, golongan, bahasa atau apapun yang ada pada bangsa Indonesia, maka sesungguhnya hakikatnya mereka adalah satu, yaitu bangsa Indonesia. Dengan modal pemahaman demikian, maka konflik yang berpangkal dari segala jenis perbedaan dengan sendirinya akan hilang. Sehingga kehidupan berbangsa dan bernegara yang aman dan damai juga harmonis akan terwujud.

\section{Penutup}

Pada era modern, heterogenitas atau kemajemukan adalah suatu hal yang tidak bisa dihindari. Menutup diri dari pluralitas adalah hal yang mustahil. Salah satu bagian dari kemajemukan adalah agama. Agama sering kali menjadi bagian komoditas politik

${ }^{15}$ Amin Abdullah, Studi Agama Normativitas dan Historisitas (Yogyakarta: Pustaka Pelajar, 2002), h. viii. 
dan kekuasaan sehingga ketika konflik terjadi agama sering dituding sebagai sumber konflik. Dalam kehidupan bernegara konflik sering kali terjadi tatkala fundamentalis sering kaliberperang, membunuh, juga meneror atas nama agama dan berusaha membawa "yang kudus" ke dalam wilayah politik dan pergulatan nasional. Konflik akan semakin meruncing bahkan abadi ketika masing-masing kelompok menjanjikan pada anggotanya bahwa merekalah wakil Tuhan sebenarnya yang dengan demikian paling sah menafsirkan ajaran Tuhan dan pembawa keselamatan tunggal. Radikalisme dan fundamentalisme agama adalah salah satu sumber penghambat pembangunan nasional. Hal tersebut bisa dihindari jika setiap orang dapat memahami bahwa kebenaran tunggal hanya dari Tuhan, dan dari Tuhanlah segala kebenaran yang lain berasal. Inilah dasar pemahaman filsafat perennial. Dengan memahami bahwa segala realitas yang muncul sebenarnya adalah wujud manifestasi dari sang Tunggal, maka semboyan Bhinneka Tunggal Ika menjadi semakin relevan untuk dipraktekkan. Jika hal tersebut terjadi, maka segala macam diversitas akan mudah diterima. Dengan demikian maka kehidupan berbangsa dan bernegara di Indonesia akan berjalan dengan baik, damai, dan tenteram. [.]

\section{Daftar Pustaka}

Bakhtiar, Amsal, Filsafat Agama Wisata Pemikiran dan Kepercayaan Manusia, Jakarta: Rajawali Pers, 2014.

Dhavamony, Mariasusai, Fenomenologi Agama (Yogyakarta: Kanisius, 1995)

Gazalba, Sidi, Ilmu Filsafat dan Islam Tentang Manusia dan Agama, Jakarta: Bulan Bintang, 1978

Hidayat, Komaruddin, Tragedi Raja Midas Moralitas Agama dan Krisis Modernisme, Jakarta: Paramadina, 1998

Hidayat, Komaruddin dan Muhammad Wahyuni Nafis, Agama Masa Depan Perspektif Filsafat Perennial, Jakarta: Gramedia Pustaka Utama, 2003.

Koentjaraningrat, Kebudayaan Mentalitas dan Pembangunan, Jakarta: Gramedia, 1992 
Kuswanjono, Arqom, Ketuhanan dalam Telaah Filsafat Perenial Refleksi Pluralisme Agama di Indonesia, Arqom, Yogyakarta: CV Arindo Nusa Media, 2006.

Mariasusai, Dhavamony, Fenomenologi Agama, Yogyakarta: Kanisius, 1995.

Nasr, Sayyed Hussein, Inteligensi \& Spiritualitas Agama-agama, Jakarta: Inisiani Press, 2004

Permata, Ahmad Norma, Perenialisme Melacak Jejak Filsafat Abadi, Yogyakarta: Tiara Wacana, 1996.

Rasjidi, M, Filsafat Agama, Jakarta:Bulan Bintang, 2002

Sirry, A. Mun'im, Membendung Militansi Agama Iman dan Politik dalam Masyarakat Modern, Jakarta: Erlangga, 2003

Sukardji, K, Agama-agama Yang Berkembang di Dunia dan Pemeluknya, Bandung: Angkasa, 2007.

Wora,Emanuel,PerenialismeKritikatasModernismedan Postmodernisme, Yogyakarta: Kanisius, 2006. 
Muhammad Nur 